\title{
Morphology of the Bracts in Welwitschia mirabilis.
}

\author{
BY
}

\section{H. TAKEDA.}

\section{With Plate XLI and two Figures in the Text.}

$\mathrm{T}$ $\mathrm{HE}$ morphology of the bracts in the inflorescence of Welwitschic has been studied by not a few botanists, and there seems to be very little to add to our previous knowledge in regard to the external configuration, whereas several interesting points on the internal structure will be described in the following pages.

The material used for my investigation was chiefly from that collected by Professor Pearson in Damaraland in January; I904, and was preserved in methylated spirit. There were bracts in different stages of development from various parts of inflorescence. There are two kinds of bracts : (I) those at the forking of the inflorescence-axis, in the axil of which a branch with cones is inserted; (2) those in the cone itself, and usually subtending a flower in each axil. For the present study attention was chiefly concentrated on the latter, although the former were also investigated for comparison.

External Morphology. This has already been described and figured in many publications, ${ }^{1}$ so that it is quite unnecessary to describe it in detail.

The bracts are broadly ovate. In the female cone the basal two or three pairs of bracts are connate, while all others are free, as has already been pointed out by the previous workers. In the male cone, on the other hand, all the bracts are connate throughout the cone. This character has never been correctly described or figured before, although it is an interesting and important point. In all the genera of the Gnetales the bracts are

1 J. D. Hooker : On Welwitschia: a New Genus of Gnetaceae, in Trans. Linn. Soc., London, xxiv, 1863. E. Strasburger: Die Coniferen und die Gnetaceen, 1872; Die Angiospermen und die Gymnospermen, 1879. Eichler, in Engler u. Prantl: Die natürlichen Pflanzenfamilien, ii, I887. A. B. Rendle: The Classification of Flowering Plants, i, 1904. H. H. W. Pearson : Some Observation on Welweitschia mirabilis, in Phil. Trans. Roy. Soc., London, B, 198, 1906; Further Observations on Welwitschia mirabilis, ibid., 20I, I909. J. M. Coulter and C. J. Chamberlain : Morphology of Gymnosperms, IgIo. M. G. Sykes: On the Anatomy and Morphology of the Leaves and Inflorescences of Welwitschia mirabilis, in Phil. Trans. Roy. Soc., London, B, 20I, I910. Gardeners Chronicle, July $23,1898$.

[Annals of Botany, Vol. XXVII. No. CVII. July, I913.] 
invariably decussate and connate at the base, as are their leaves also. But this character does not occur in any other group of the Gymnosperms, except that opposite cone-scales are found in certain members of Cupressineae.

The Nervation. The vascular supply in the bracts strikingly differs from the nervation of the leaf, inasmuch as the shape of these two organs differs, yet there exists a feature of homology between them. The leaf and cotyledon receive the paired bundles, and so does the bract. In the case of the leaf, the primary design of the nervation is subsequently altered by the formation of the new additional bundles, whereas in the cotyledon the primitive character is retained. ${ }^{1}$ Supposing the main bundles in the cotyledon were telescoped and the transverse veins were to end blindly, then the nervation of the bract would be produced.

The bract at the node of the inflorescence is very thick in texture, short, and broadly connate. It has a nervation quite similar to that of the other bracts, except that this is less freely branched.

The Epidermis. The epidermal cells of the adaxial side of the bract are flat and smooth (Pl. XLI, Fig. 3). The outer wall of the cell is fairly thick and chiefly consists of cellulose, and is uniformly covered with thin cuticle. The epidermal cells of the abaxial side are not flat, but are rather uneven owing to the vault-like shape of each cell (Fig. 2). The outer wall is comparatively thin. That of the female cone chiefly consists of cellulose covered with a thin layer of cuticle, while that of the male cone shows two layers; they are the inner cellulose and the outer cuticularized layer. Minute granules of calcium oxalate are present in the outer epidermal cells. In the female cone-bract they are deposited in the cellulose layers of the outer wall, whilst in the male cone-bract they are impregnated in the cuticularized layer of the outer wall as well as in the inner wall, which is chiefly composed of cellulose (Figs. 2, 3). In the case of the bract subtending the cone-stalk the epidermal cells of both sides are practically flat (Fig. 4). The nature of the cell-wall and that of the deposit of calcium oxalate of this kind of bract entirely correspond to those of the cone-bract of its own inflorescence, namely the bract of the male inflorescence has the cuticularized layer, and the calcium oxalate deposited in both the outer and inner cell-walls, while in that of the female inflorescence the cuticularized layer and the crystals of calcium oxalate in the inner epidermal wall are absent.

Each epidermal cell is generally quadrangular in the surface view, and is elongated longitudinally resembling that of the cotyledon. ${ }^{2}$

In the outer epidermal cells, especially of the cone-bracts, chloroplasts

1 Takeda, H.: Some Points in the Anatomy of the Leaf in Welzuitschia mirabilis, in Ann. Bot., xxvii, I9I3, p. 348 .

2 Takeda, H., l. c., p. 349. 
are present, and starch is produced in these, as in the case of the epidermal cells of the leaf and stem in Ephedra.

The Stoma. The presence of stomata in the bracts has been noted by Hooker, ${ }^{1}$ Strasburger, ${ }^{2}$ and Sykes. ${ }^{3}$ Stomata occur in all kinds of bract. They are not so deeply sunken as in the adult leaf, but not so superficial as delineated by Sykes (Figs. 2-4). The guard-cells are much the same as those of the cotyledon in shape and structure. The ventral wall consists of cellulose, and the upper portion of the dorsal wall is thickened and slightly lignified, not giving a strong reaction to phloroglucin or aniline sulphate.

Stomata are distributed in the exposed parts of the bracts, except near the margin, and are generally longitudinally and only rarely obliquely

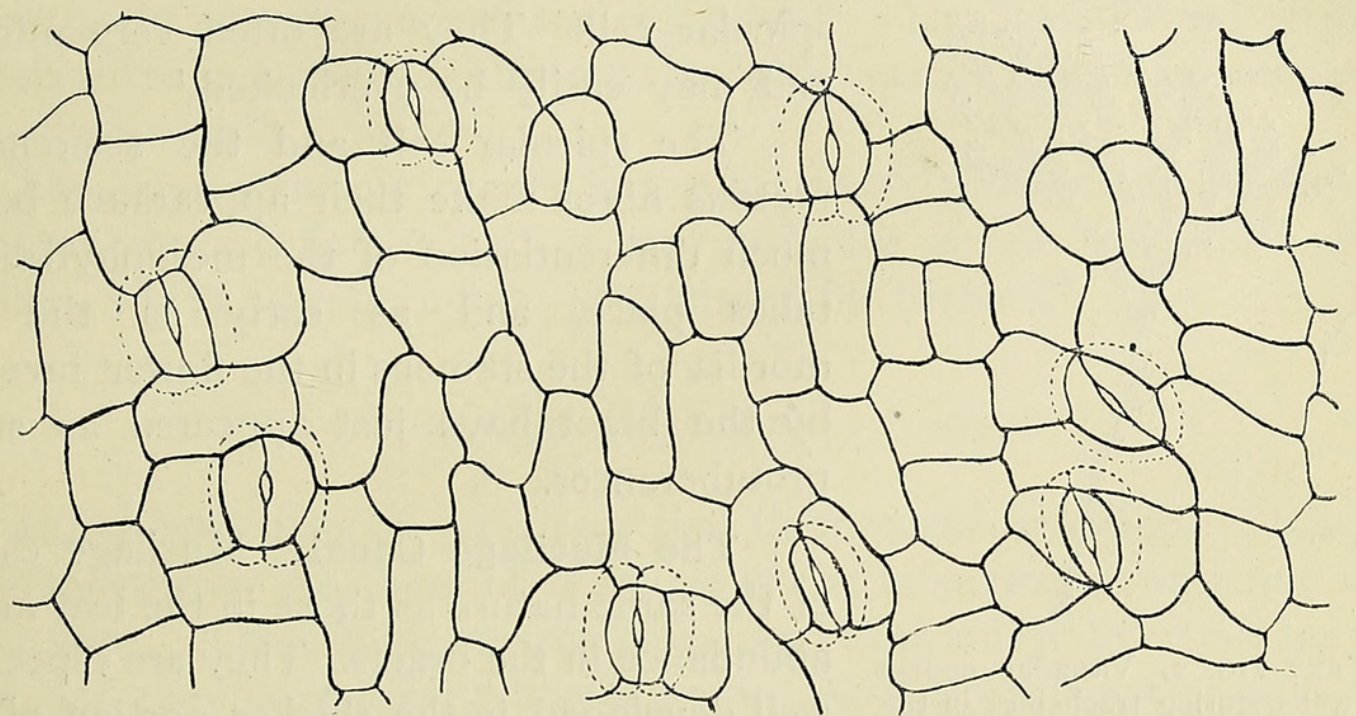

Text-Fig. I. A portion of the epidermal cell from the exposed part of the male cone-scale in surface view. $\times 285$.

orientated. The mode of their development is exactly the same as in the case of the leaf and cotyledon ${ }^{4}$ (Text-fig. I).

The Mesophyll. The exposed portion of the bract is considerably thickened, and consists, in the case of the male cone, of about six cells, and in the case of the female cone, of more than ten cells in thickness. ${ }^{5}$ In the fully developed bracts of all kinds, palisade tissue is present under the outer epidermis. This tissue is perhaps best developed in the male cone-bract and consists of one or sometimes two layers of cells. In the female conebract this tissue is greatly interrupted by the presence of spicular cells. Sykes ${ }^{6}$ did not observe any palisade; she appears to have not recognized that she was dealing with immature structures. The spongy parenchyma cells are roundish and contain chloroplasts. In the wall of these cells of full-

\footnotetext{
1 1. c., p. 25.

${ }^{2}$ 1. c. (I), p. 94 .

s 1.c., p. 185 .

${ }^{4}$ Cf. Takeda, H., 1.c., p. 35 I.

${ }_{5}^{5}$ Strasburger, E., l.c. (I), p. 94.

${ }^{6}$ 1. c., p. 185.
}

P $\mathrm{p} 2$ 
grown bracts crystals or granules of calcium oxalate are deposited as in the case of the leaf.

The unlignified sclerenchymatous fibres are present in large quantity, and they are, in the cone-bracts, usually disposed under the inner epidermis, and in the other kind of bract are scattered in the mesophyll. These are the sole strengthening cells in the connate portion of the bract, which is not traversed by the vascular bundles. The fibres are not always straight, but are often curved or wavy.

The Spicular Cell. The spicular cells occur copiously in different parts of the mesophyll. They are straight in the thinner portions of the bract, but are bent and irregularly branched in the thicker portion. Crystals or granules of calcium oxalate are

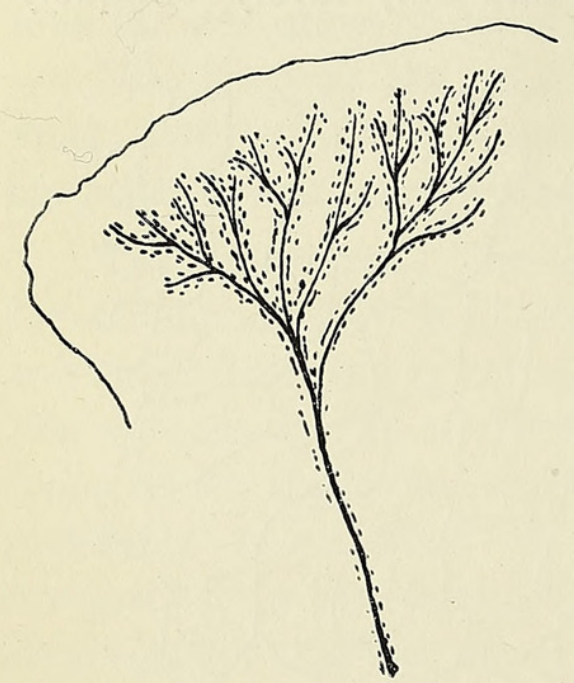

TeXt-FIG. 2. Vascular course with water-storing tracheides in the male cone-bract. $\times$ I 2. Prepared from material cleared with eau de Javelle. (Only half of the bract is shown.)

found in the outer lignified layer of the spicular cell. They are often very minute, and may easily be overlooked. ${ }^{1}$

The spicular cell and the sclerenchymatous fibres make their appearance before much differentiation of the mesophyll-tissue takes place, and as early as the primordia of the stamens in the flower invested by the bract have just appeared as small protuberances.

The Mucilage Canal. Mucilage canals of the same nature as those in the leaf are in abundance in the bracts. They are especially well developed in the thicker portion of the bract, and are very irregularly branched. ${ }^{2}$

The Vascular Bundle. The bundles are collateral and normally orientated. The xylem consists of loose spiral and annular elements of protoxylem and of dense spiral tracheides of metaxylem. No secondary xylem is present, consequently no tracheae are found. All these elements possess bordered pits at intervals on their radial and tangential walls. The pits are not formed in perfection. They are of oval or circular shape and have rather elongated orifice; a torus has not been observed. The phloem consists of narrow sieve-tubes and phloem-parenchyma. The sclerenchymatous fibres have been observed only in the bract at the node of the inflorescence axis, and there are only a few elements present on the phloem side (Fig. 5).

The Water-storing Tracheides. The vascular bundle of the bract is accompanied by water-storing tracheides on its whole course. The tracheides

$$
1 \text { Cf. Sykes, 1. c., p. } 185 \text {. } 2 \text { Sykes, 1. c. }
$$


are comparatively few in the lower part of the bract, and are scattered here and there along the bundle. Higher up in position they increase in amount, and are better developed on the phloem side. In these cases the tracheides are generally elongated in the longitudinal direction. Towards the apex of the bract, where the bundles ramify freely, the tracheides reach their maximum development. They surround the bundles nearly completely. They often even extend in lateral directions, and sometimes they occupy the space between bundles, thus replacing a large part of the mesophyll. The elements are not always connected with each other, but occasionally occur isolated among the mesophyll-parenchyma. The general disposition of the tracheides can be very well seen in a preparation cleared with eau de Javelle (Text-fig. 2).

The first-formed elements arise usually on the lateral side of the bundle, just as in the case of the leaf and cotyledon. ${ }^{1} \quad$ The later-formed elements are derived from mesophyll-parenchyma, which can be traced by comparison with adjacent cells.

The same structure occurs in the bracts of Gnetum and of Ephedra (not in the male inflorescence), as well as in the female cone-scales of the Conifers, which have been fully investigated by Bernard. ${ }^{2}$

\section{Summary and Conclusions.}

It has been pointed out above that there occur two kinds of bracts in the inflorescence, viz. those at the node of the inflorescence axis, and those in the cone. There is no morphological and anatomical difference between them, and they are perfectly homologous. All the bracts are broadly ovate and are, except those in the upper portion of the female cone, connate at the base.

Each bract receives a pair of bundles which branch copiously towards the apex of the bract. The nervation is closely comparable with that of the cotyledon, which possesses the phylogenetically primary arrangement of vascular supply.

In the outer epidermis stomata are found abundantly, and in their structure they are identical with those of the leaf. Chloroplasts are present in the epidermal cells of the cone-scale.

The mesophyll is differentiated into palisade tissue and roundish parenchyma cells. These are full of chloroplasts and form chlorenchyma. Spicular cells with crystals of calcium oxalate and sclerenchymatous fibres with unlignified walls are present in the mesophyll. Irregularly branched mucilage canals are also found in abundance.

${ }^{1}$ Cf. Takeda, H., 1. c., p. 354 .

2 Bernard, Ch.: Le bois centripète dans les bractées et dans les écailles des Conifères, in Beihefte z. Bot. Centralbl, xvii, I904. 
The vascular bundles are collateral and normally orientated. They are, particularly in the exposed portion of the bract, completely surrounded by a mass of water-storing tracheides, as in the leaf.

From the facts above mentioned it is to be seen that the bracts are perfectly homologous with the vegetative leaf. It is also to be seen that the cone-bracts are bracts in the strict sense, in the axil of which the 'flower' is borne. Sykes ${ }^{1}$ is inclined to regard the bract as a sporophyll. This hypothesis is, however, open to the objection that the structure is too highly differentiated tor a sporophyll of such an advanced member of the Gymnosperms. Moreover, the 'flower' is, without doubt, cauline. Each cone is therefore a compound one.

I may perhaps emphasize here the connate character of the bract, which is one of the important diagnostic features of the Gnetales. The connate leaf-base so universal in the Gnetales has already been pointed out in my former paper. ${ }^{2}$ The homology of the inflorescences of the three genera of the Gnetales becomes easily intelligible, if this character is taken into consideration. Hooker ${ }^{3}$ has already noticed the resemblance of the female cones of Welwitschia and of Ephedra, particularly in the bracts, on account of the paired bundles, the presence of stomata, and so forth. He, however, seems to have failed in finding connate bracts in Welwitschia. This difficulty is easily overcome, if one examines the male cone closely. Even in the female cone the few basal pairs are connate.

The connate character would probably help us to interpret the peculiar tubular structure of the stamens in Welwitschia as a fused base of two groups of male sporophylls.

In conclusion, I tender my sincere thanks to Professor Farmer for his kindly criticism.

\section{EXPLANATIONS OF PLATE XLI.}

Illustrating Mr. Takeda's paper on the Bracts in Welwitschia.

All figures were drawn faithfully by the aid of Abbé's drawing apparatus.

Fig. I. Transverse section of a vascular bundle of the male cone-bract, taken from the middle portion of the latter. $\times{ }_{28} 8_{5} . \quad c . j .=$ conjunctive parenchyma; w.t. $=$ water-storing tracheides.

Fig. 2. Epidermis with stomata and a portion of chlorenchyma (from a transverse section of a male cone-bract). $\times 285$. Cell contents are not shown.

Fig. 3. A portion of a longitudinal section of the male cone-bract (near the apex). $\times 285$. Cell contents are not represented. St. $=$ stoma $; S p .=$ spicular cell.

Fig. 4. Epidermis and chlorenchyma of the bract at the node of the male inflorescence. $\times 285$. Sc. $=$ spicular cell.

Fig. 5. Transverse section of a vascular bundle of the same bract (taken from the middle portion of the bract). $\times 285 . f=$ sclerenchymatous fibres with unlignified walls.

Fig. 6. A portion of a longitudinal section of two protoxylem elements of the female conebract. $\times 95^{\circ}$. Spiral vessel on the right, and annular vessel on the left.
1. c., pp. $219,22 \mathrm{I}$.
2 1. c.
${ }^{3}$ 1.c., p. 25. 
Arnats of Botany
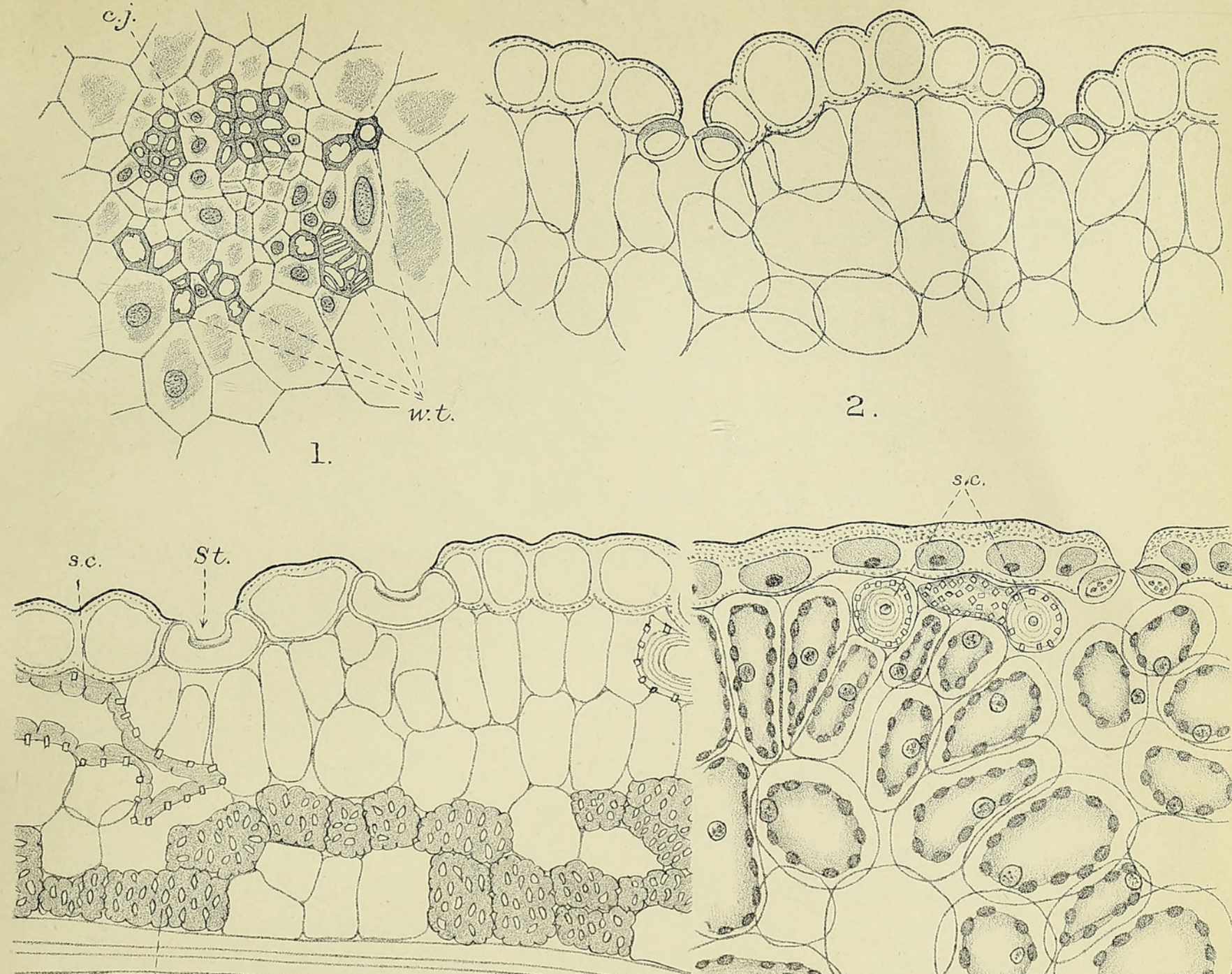

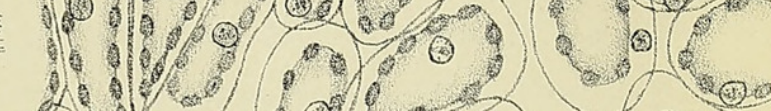

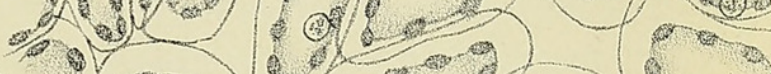

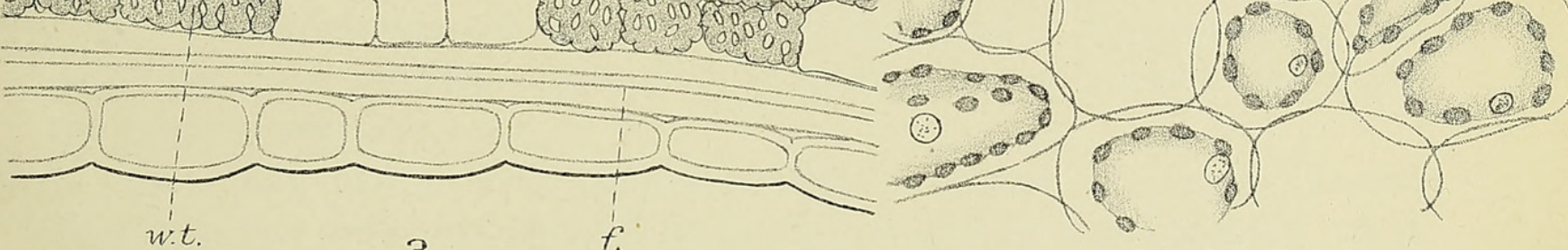

3

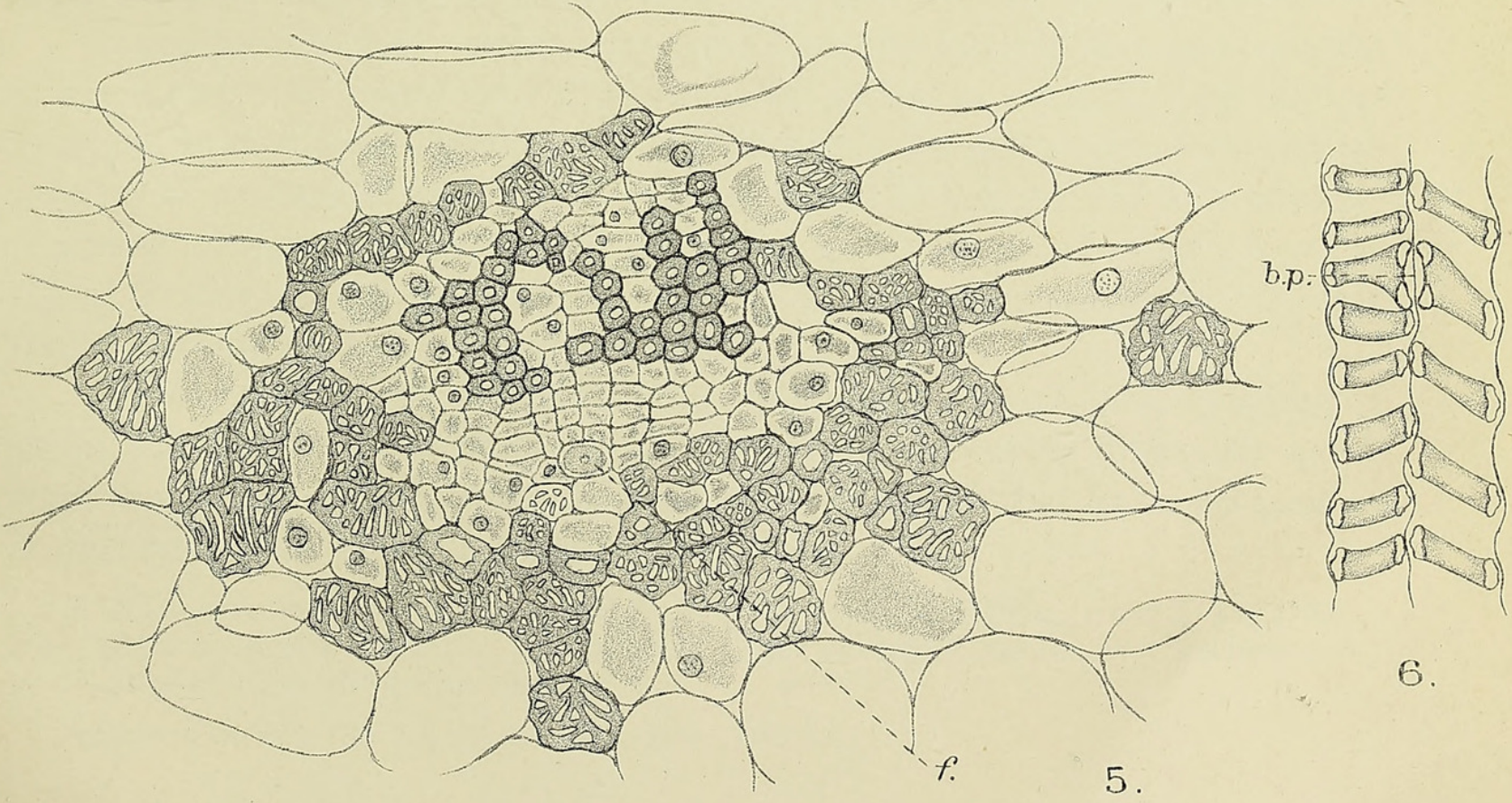

TAKEDA - WELWITSCHIA.

Huth lith.et imp. 


\section{$2 \mathrm{BHL}$ Biodiversity Heritage Library}

Takeda, H. 1913. "Morphology of the bracts in Welwitschia mirabilis." Annals of botany 27, 547-552. https://doi.org/10.1093/oxfordjournals.aob.a089474.

View This Item Online: https://www.biodiversitylibrary.org/item/237410

DOI: https://doi.org/10.1093/oxfordjournals.aob.a089474

Permalink: https://www.biodiversitylibrary.org/partpdf/319987

\section{Holding Institution}

Smithsonian Libraries

\section{Sponsored by}

Biodiversity Heritage Library

\section{Copyright \& Reuse}

Copyright Status: Not in copyright. The BHL knows of no copyright restrictions on this item.

This document was created from content at the Biodiversity Heritage Library, the world's largest open access digital library for biodiversity literature and archives. Visit BHL at https://www.biodiversitylibrary.org. 